\title{
Sea Surface Temperature Variability in the Florida Keys and Its Relationship to Coral Cover
}

\author{
I. M. Soto, F. E. Muller Karger, P. Hallock, and C. Hu \\ College of Marine Science, University of South Florida, 140 7th Avenue South, St. Petersburg, FL 33701, USA \\ Correspondence should be addressed to I. M. Soto, isoto@mail.usf.edu
}

Received 31 March 2011; Accepted 21 June 2011

Academic Editor: E. A. Pakhomov

Copyright () 2011 I. M. Soto et al. This is an open access article distributed under the Creative Commons Attribution License, which permits unrestricted use, distribution, and reproduction in any medium, provided the original work is properly cited.

The hypothesis that moderate variability in Sea Surface Temperature (SST) is associated with higher coral cover and slower rates of decline of coral cover within the Florida Keys National Marine Sanctuary (FKNMS) was examined. Synoptic SST time series covering the period 1994-2008 were constructed for the FKNMS with the National Oceanic and Atmospheric Administration Advanced Very High Resolution Radiometer satellite sensors. The SST data were compared with coral-cover time-series data from 36 sites monitored by the Coral Reef and Evaluation Monitoring Program. Sites that experienced moderately high SST variability relative to other sites showed a trend toward higher percentage coral cover in 2008 and relatively slower rates of decline over the 14 -year study period. The results suggest that corals at sites that are continuously exposed to moderate variability in temperature are more resilient than corals typically exposed either to low variability or to extremes.

\section{Introduction}

The disruption to the symbiotic relationship between corals and their zooxanthellae known as coral bleaching is a common stress response to one or multiple disturbance events [1-6]. Coral mass-bleaching events have primarily been associated with elevated photo-oxidative stress caused by high levels of solar irradiance, prolonged sea temperatures warmer than normal conditions, or both $[1,2,7-11]$. Anomalously low temperatures can also trigger bleaching $[1,12,13]$. Moreover, natural or anthropogenic exposure to somewhat elevated nutrient flux can lower warming thresholds for bleaching $[14,15]$.

The upper temperature threshold for bleaching also can be influenced by the thermal history of the reef site, season and environmental background $[16,17]$. Sammarco et al. [18], for example, found that not all reef sites studied exhibited mass bleaching during anomalously high mean temperatures in Puerto Rico. However, bleaching occurred when both high biweekly mean temperatures and high sea surface temperature (SST) coefficients of variation were present.

A record of SST variability can provide insights about the thermal history of a coral reef. McClanahan and Maina
[19] found that coral cover was inversely proportional to the temperature variation experienced in four reef sites in Kenya's southern fringing reef. Yet an opposite relationship was found regarding taxonomic richness [19, 20]. McClanahan et al. [17] and Ateweberhan and McClanahan [21] also found that coral bleaching responses to warm-water anomalies were negatively correlated with temperature variability in coral reefs in East Africa and for 36 major reef areas in the Western Indian Ocean region during the 1998 bleaching event, respectively. Thompson and van Woesik [22] found that coral reef sites around the world that had high-frequency SST variability experienced more stress during the 1998 global bleaching event. However, during the 2005-2006 bleaching event, sites with high-frequency SST variability experienced less bleaching than expected. Using ecological modeling, Maina et al. [23] suggested that SST variability, temperature, and ultraviolet (UV) radiation were the best predictors of bleaching, with bleaching prevalence declining with SST variability but increasing with mean and maximum temperatures and UV radiation.

All these results suggest the possibility of adaptation or acclimatization under thermal stress, often accompanied by loss of vulnerable taxa. The "intermediate disturbance 
hypothesis" of Connell [24] contends that, without disturbances, communities should reach an equilibrium in which competitively superior species exclude others, thereby locally reducing species richness. A disturbance that kills or damages individuals will set back the process of competitive exclusion and open new space that can be colonized by less competitive taxa, thereby locally increasing species richness [24]. Evidence that this concept applies in coral ecosystems was collected in Jamaica, where Porter et al. [25] documented a decrease from $51-54 \%$ to $10-12 \%$ in benthic cover of Acropora spp. in shallower reefs (less than $10 \mathrm{~m}$ ) in 1980 after hurricane Allen, opening space for less dominant species.

Another fundamental assumption of the Connell hypothesis is that, if disturbance occurs too frequently, species richness will decrease and species that are tolerant of disturbances or that can recruit quickly will become more abundant [26]. Kenya's reefs seem to be an example of this based on the effects of the 1998 bleaching event $[19,20]$. Extreme disturbance events, including lethal occurrences of low or high temperatures, can negatively impact both coral cover and species richness following the event. If such events occur with sufficient frequency or scale to limit recruitment, both coral cover and species richness will likely decline over larger spatial and temporal scales [2, 27].

The coral reefs of the Florida reef tract are a major economic resource, supporting approximately $\$ 490$ million a year in sales and 8,000 jobs [28]. Decline in coral cover has been a concern since the late 1970s, when the first observations of bleaching and disease outbreaks were recorded [29, 30]. Concern for the reefs resulted in the establishment of a variety of local, state, and national parks, as well as the Key Largo National Marine Sanctuary in 1975 and the Looe Key National Marine Sanctuary in 1981. In 1990, management was extended throughout the reef tract with establishment of the Florida Keys National Marine Sanctuary (FKNMS). The need for better understanding of sanctuary environments and natural resources resulted in funding of several longterm monitoring programs [31-34]. Specifically, Ogden et al. [34] highlighted the importance of collecting long-term temperature time series to understand changes in coral reef ecosystems. At about the same time, the Coral Reef Evaluation and Monitoring Program (CREMP) was designed and implemented to provide species inventories and a time series of data quantifying coral cover $[32,35,36]$. The field work began in 1996, collecting video transects and other data at 40 sites spread throughout the Florida Keys. The program documented major losses of coral cover in 1998 and 1999 due to the 1998 mass bleaching event [32].

The CREMP coral-cover time-series data also documented a surprising trend, specifically that coral cover of offshore reefs had declined much faster than inshore patch reefs $[31,37,38]$. Inshore patch reefs are exposed to higher environmental variability (temperature, salinity, and water quality) due to the vicinity and influx of Florida Bay waters [36, 39-41]. Indeed, the higher coral-cover and the lower rates of decline in comparison to offshore reefs represents a paradox.

In this study, we address this paradox by examining Connell's [24] intermediate disturbance hypothesis and the possibility of acclimatization $[5,6,42]$. We postulate that the higher rates of survival of coral populations on the patch reefs are a consequence of their exposure to, and therefore acclimatization to greater temperature variability, in comparison to their offshore counterparts. To test this concept we used a time series of satellite-derived Sea Surface Temperature (SST) observations collected between 1994 and 2008 and compared it with change in coral cover recorded by the CREMP from 1996 through 2008.

\section{Methods}

2.1. Coral-Cover and Cover-Change Data. The FKNMS has a surface area of $\sim 9,950 \mathrm{~km}^{2}$ and contains nearshore and offshore patch reefs, seagrass beds, back reefs and reef flats, hard-bottom communities, bank or transitional reefs, deep reefs, outlier reefs, and sand/soft bottom areas $[31,33]$. In 1996, the CREMP initiated annual video transects collections to quantify benthic coral cover and to assemble coral species inventories. Data were collected at 40 sites spread throughout the Florida reef tract (Figure 1). Three sites in the Dry Tortugas were added in 1999. Porter et al. [32] provided details of the program methods and procedures. The 43 sampling sites include 7 hardbottom, 11 patch, 12 offshore shallow, and 13 offshore deep reef sites. We did not include the hardbottom sites in our assessment due to the extremely low abundance of stony coral at these locations.

For the remaining 36 sites (Figure 1), the CREMP parameters utilized included percent of stony coral cover present in 2008 and the coral-cover change (the difference of stony coral cover) between 1996 and 2008. For the three Dry Tortugas sites established in 1999, coral-cover change was estimated only from 1999 to 2008. The overall change observed in 2008 was normalized by the percent of stony coral observed in 1996, except for the Dry Tortugas where we used 1999. Annual coral-cover change was normalized by the coral cover of the previous year. The regional annual mean coral-cover change was then estimated by averaging the estimates for the 36 sites with the longer record. Smith Shoal was not included in the regression and correlation analyses because it is located outside the reef track; however, it was included in the discussion to highlight special conditions observed there.

2.2. Temperature Variability. Full-resolution $\left(1 \mathrm{~km}^{2}\right)$ infrared (IR) data were derived from the Advanced Very High Resolution Radiometer (AVHRR) sensors onboard the NOAA polar-orbiting environmental satellites (POES). The images were collected using a High Resolution Picture Transmission (HRPT) antenna located at the University of South Florida, in St. Petersburg, FL, USA. The SST was calculated from satellite infrared observations using the multichannel sea-surface temperature (MCSST) algorithm developed by McClain et al. [43]. All SST images from 1994 to 2008 were collected and mapped to a cylindrical equidistant projection at approximately $1-\mathrm{km}$ spatial resolution. A complete description of the AVHRR data processing and navigation used by the University of Florida can be found in the supplemental materials section of $\mathrm{Hu}$ et al. [44]. 

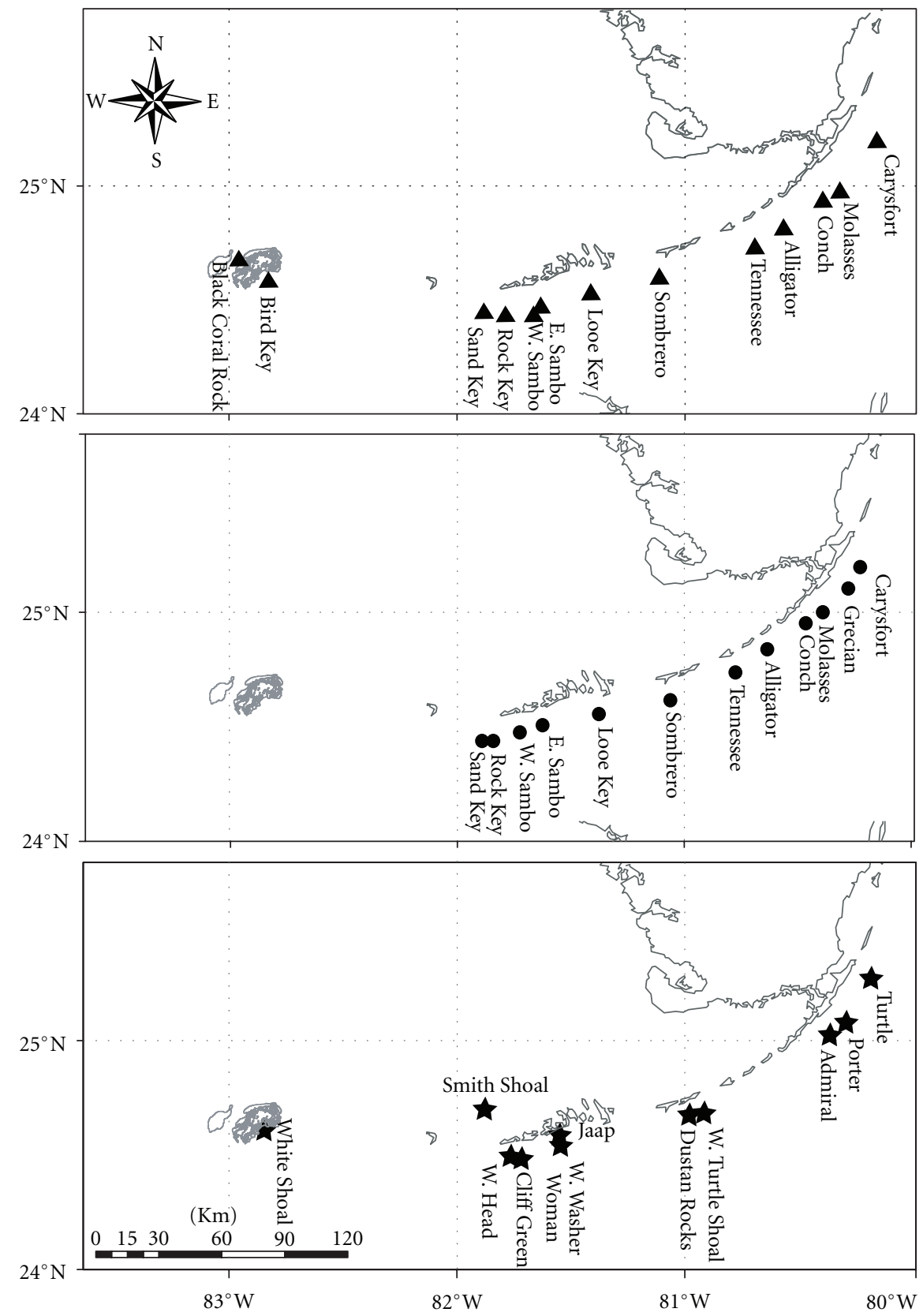

FIgure 1: Location of the CREMP sites in the Florida Keys National Marine Sanctuary. (Top panel) offshore deep reefs; (middle panel) offshore shallow reefs; (bottom panel) patch reefs.

While the coral cover observations started in 1996, SST images from 1994 were used in this study to assess SST variability using the longest time series available.

To minimize issues with spurious SST observations due to poor cloud screening, a cloud filtering technique [44] was applied to the imagery. A weekly SST climatology was derived, and each individual SST image collected was compared pixel by pixel with the values in the corresponding weekly climatology file. Instantaneous SST estimates that showed an absolute value difference higher than $4^{\circ} \mathrm{C}$ were discarded from further treatment. Additional treatment included computing a three-day median filter where SST values differing by at least $2^{\circ} \mathrm{C}$ from the calculated median value at each pixel were discarded. Hu et al. [44] validated the filtered SST data using near-surface temperature observations from 12 buoys (U.S. National Oceanic Atmospheric Administration National Data Buoy Center, NOAA NDBC) located near the Florida Keys. For nine of the NDBC stations, selected away from land to minimize possible contamination by terrestrial infrared emissions, the correlation between the in situ and satellite SST is excellent (mean rms $=0.90^{\circ} \mathrm{C}$, mean $\mathrm{SD}=0.84^{\circ} \mathrm{C}$, slope $=0.9$, intercept $=2.2$, and mean bias $=-0.29^{\circ} \mathrm{C}$ ) [44]. The small statistical bias in SST is likely a result of residual cloud contamination errors [44]. 
It does not affect our analysis of SST variability and coral cover, because any bias in the data is eliminated in the computation of variability.

The AVHRR SST data represents near-surface (bulk) ocean temperatures. The temperatures experienced by individual coral colonies, especially those located in deeper waters, are often not identical to the overlying SST values. Wagner et al. [45] compared surface and near-substrate temperatures during the summer of 2008 and found that the differences often exceeded $1^{\circ} \mathrm{C}$ at sites deeper than $10 \mathrm{~m}$. The mean maximum depth of the CREMP sites we examined was $5 \mathrm{~m}$ for patch reefs, $4 \mathrm{~m}$ for offshore shallow, and $14 \mathrm{~m}$ for offshore deep sites. Two thirds of the sites are less than $10 \mathrm{~m}$ deep; only Black Coral Rock (Figure 1) exceeded $16 \mathrm{~m}$ depth. Unfortunately, we did not have access to near-substrate temperature data for any of the CREMP sites. Here we make the assumption that the variability in the SST data provides a good index (within $1^{\circ} \mathrm{C}$ ) of the variability in temperatures experienced by these shallow reefs, even though we know that episodic upwelling events increase variability at the sea floor.

SST data were extracted at every site from the AVHRR overpasses collected from 1994 to 2008 (>50,000 images). Daily and weekly mean SSTs were calculated for each site, as well as the variance of the weekly averaged temperatures for the 15-year period (in total, approximately 780 weekly observations). The variance was then compared with percentage of coral-cover change and percentage coral cover observed in 2008. Robust regression and correlation-coefficient analyses were used to examine relationships between SST variance, percentage of coral cover in 2008, and percent change in coral cover between 1996 and 2008. One-way ANOVA analysis was used to determine whether there were significant differences between coral cover and change in coral cover exposed to low and high SST variances.

Because CREMP data were collected each summer between May and August, we estimated the thermal history experienced by the reefs for the preceding year by computing "annual" SST statistics for the period spanning the previous 1st May to 31st April. For example, for CREMP data for summer 2000, we computed the thermal history for the previous year from SST data for May 1999 through April 2000. The basic regional statistics calculated for each "year" included annual mean regional SST, standard deviation of the annual SST mean, annual SST variance, and annual SST minimum and maximum. Also, the number of weeks with SST above $29.5^{\circ} \mathrm{C}$ and $30^{\circ} \mathrm{C}$ was counted. The annual statistics were compared with the mean change in coral cover. A time series (1994-2008) of regional weekly SST was also created by averaging the weekly SST derived for the 36 sites. All statistical analyses were done using MATLAB.

\section{Results}

Only six of the 36 CREMP sites showed more than $15 \%$ stony-coral cover in 2008 (Western Washer Woman, Western Head, Admiral, Jaap Reef, Black Coral Rocks, and Dustan Rocks). The maximum coral cover was 23\% at Admiral Reef. Average stony-coral cover for all sites was $11.9 \%$ in 1996, declining to $6.6 \%$ by 2004 [46]. Coral cover then remained relatively constant through 2008, at an average of $7 \%$ [47].

Our results show that locations with higher coral cover in 2008 generally exhibited higher weekly SST variance (Figure 2(a), $r=0.70, P=2.9 \times 10^{-6}, N=35$ ). The ten locations with more than $10 \%$ coral cover in 2008 featured weekly SST variance that exceeded $6^{\circ} \mathrm{C}$. The SST variance at all the patch reefs exceeded $6^{\circ} \mathrm{C}$, with 7 of the 11 exceeding $12 \%$ coral cover. Only two offshore-deep reefs exhibited over $10 \%$ coral cover (Bird Key and Black Coral Rock). The other 11 offshore-deep sites, as well as 10 of the 12 offshore-shallow reefs, had less than $6 \%$ coral cover and were characterized by SST variance less than $6.5^{\circ} \mathrm{C}$.

All CREMP reef sites except for one patch reef exhibited decline in coral cover between 1996-1999 and 2008 (Figure 2(b)). The weekly SST variance also explained a significant portion of the average rate of coral-cover decline $(r=0.44, P=0.008, N=35)$. Percent change at all sites varied widely, from nearly $8 \%$ increase (Dustan Rocks patch reefs) to over $89 \%$ loss (Western Sambo shallow reefs). All of the offshore reefs exhibited at least 30\% loss in coral cover; two-thirds of the offshore-shallow sites and 4 of 13 offshoredeep sites lost more than $65 \%$ of the coral cover recorded in 1996. Only 7 of the 25 offshore reefs experienced SST variance that exceeded $6^{\circ} \mathrm{C}$.

Smith Shoal was not included in Figure 2. It showed weekly SST variance of $\sim 11^{\circ} \mathrm{C}$ over the period of observation, with $\sim 3 \%$ coral cover in 2008 and nearly $80 \%$ decline in coral cover since 1996. When Smith Shoal was included in the regression analyses of coral cover at CREMP sites (Figure 2(a)), the correlation coefficient between coral cover and SST variance decreased from 0.70 to $0.50(P=$ $0.002, N=36$ ). Similarly, the Smith Shoal data caused the correlation between coral-cover change and SST variance (Figure $2(\mathrm{~b}))$ to decrease from 0.44 to $0.22(P=0.21, N=$ 36).

In addition to linear regression, a one-way ANOVA was performed to study the relationship between SST variance and coral cover and change in coral cover. We chose $6^{\circ} \mathrm{C}$ variance as a place to start our analyses. Below $6^{\circ} \mathrm{C}$, all sites had less than $10 \%$ coral cover, and $94 \%$ of these showed less than $6 \%$ cover (one site had $\sim 8 \%$ ). A one-way ANOVA revealed significant differences between reefs with SST variances above and below $6^{\circ} \mathrm{C}$ (coral cover $P=0.0002$ and coral cover change $P=0.017$ ).

The SST weekly mean time series (1996 to 2008) constructed by averaging the series at all 36 sites is shown in Figure 3. The annual change in coral cover and statistical analysis for Figure 3 are presented in Table 1. The CREMP data for the Florida reef tract show that the decrease in cover (negative rates of change) was high from 1997 to 1998 (over 21\% loss), 1998-1999 (over 23\% loss), and 2005 to 2006 (an additional 19\% loss). Our analyses show that the mean "annual" (1 May to 31 April) SST variance during 1997-1998 and 2005-2006 was very high (over $7.5^{\circ} \mathrm{C}$ ) relative to other periods. The three years with the highest coral loss also experienced temperatures above $30^{\circ} \mathrm{C}$ for over 3 weeks. In addition, in 1998-99 the warm temperatures above $29.5^{\circ} \mathrm{C}$ lasted for more than 8 weeks, although the SST 


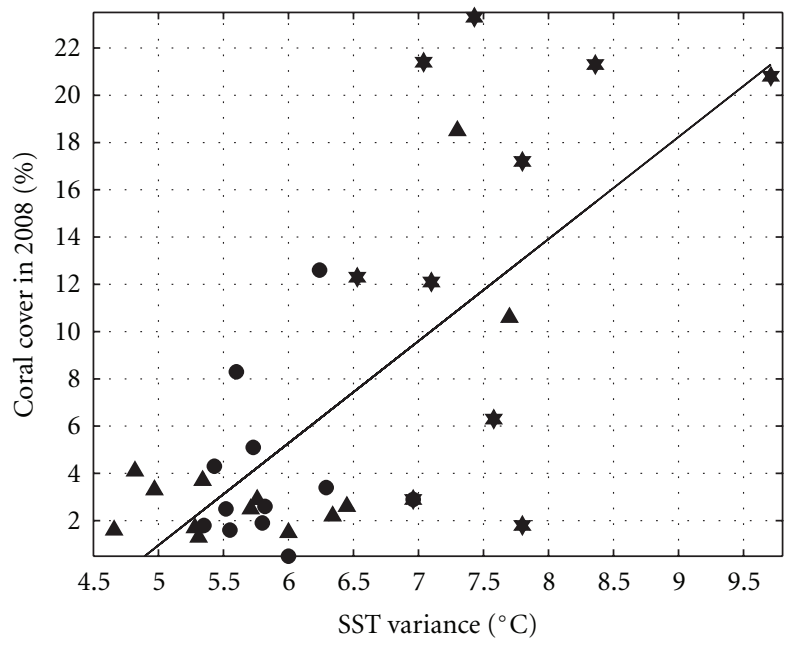

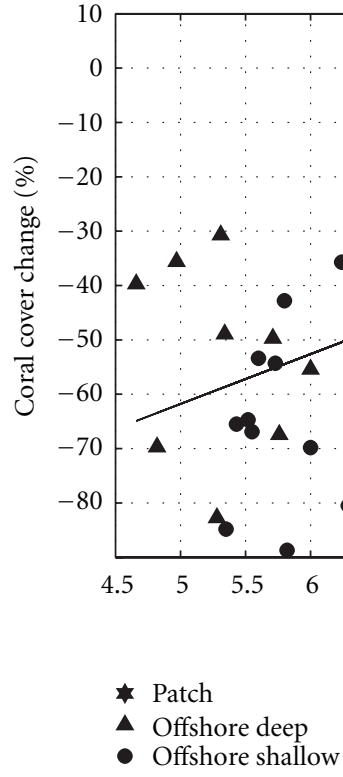

- Offshore shallow

(a)

(b)

Figure 2: (a) Comparison between percentage of coral cover in 2008 and weekly SST variance from 1994 to $2008\left(r=0.70, P=2.9 \times 10^{-6}\right.$, robust fit equation: $y=0.04 \times-0.21, N=35$ ). (b) Comparison between percentage of coral cover change from 1996-1999 to 2008 and weekly SST variance from 1994 to 2008 ( $r=0.44, P=0.008$, robust fit equation: $y=0.09 \times-1.08, N=35$; note inverted scale in $y$-axis).

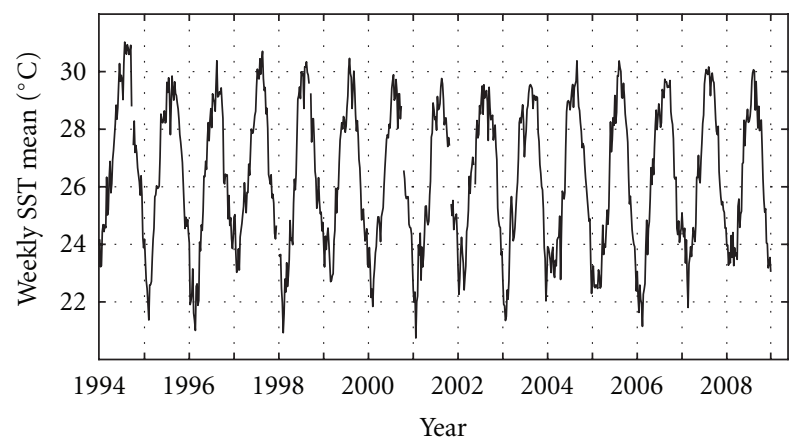

FIGURE 3: Time series of SST weekly means averaged for the 36 CREMP sites from 1994 to 2008.

mean variance was moderate. Years with lower SST variance $\left(<6^{\circ} \mathrm{C}\right)$, except 1998-99, exhibited small increases in coral cover (Table 1), despite the high number of weeks above $29.5^{\circ} \mathrm{C}$ that occurred in 2007-2008.

\section{Discussion}

A gradual decline in coral cover on the Florida reef tract, as elsewhere around the Caribbean, began in the 1960s. Sporadic bleaching events associated with unusually warm temperatures were reported by Shinn [48] and Jaap [29]. However, recovery was observed within weeks of these events. Jaap et al. [36] compiled a historical dataset for Bird Key Reef in the Dry Tortugas from 1975 to 2004 that revealed declines from $\sim 47 \%$ live coral cover in 1975 to $\sim 20 \%$ cover in 1989 .
Aside from hurricanes, winter cold events were among the first major disturbances observed by researchers in the Florida Keys in the 1960s and 1970s. Hudson et al. [49] reported that a cold-water event was responsible for coral mortality at Hen and Chickens Reef during the winter of 1969-1970. An extreme cold-water disturbance was observed in January 1978 [12, 50, 51]. Die-offs, especially in Acropora spp. stands, were observed throughout the Florida Keys but were best documented in the Dry Tortugas ([36], and references therein). Coral mortality during the cold-water event in 1978 led to a decline in cover from which many coral populations along the Florida reef tract have been unable to recover. A cold-water event responsible for extensive coral mortality was also reported during winter 2009-2010 by the Florida Reef Resilience Program and other monitoring agencies [52].

In the late 1970s and early 1980s, white-band disease, characterized by basal tissue sloughing, began to be observed in the acroporid corals of the Caribbean and western Atlantic, including the Florida reef tract [53, 54]. Peters [55] proposed the term "stress-related necrosis" for cases where cell degeneration was observed but no pathogen was detected. The decline in coral cover continued through the 1980s, as a result of two widespread mass-bleaching events in 1983 [56] and 1987 [57]. Many investigators speculate that there is a linkage between these events and the processes (as yet unknown) that led to the region-wide die-off of the sea urchin Diadema in 1983 [58]. Bleaching was also observed in the Florida Keys in 1989, 1990, and 1991 ([59], and references therein), and diseases that were previously not seen in the region were reported with increasing frequency beginning in the 1990s ([60,61]; others). Porter and Meier 
TABLE 1: Statistical summary of the weekly SST mean time series and comparison with annual mean coral cover change.

\begin{tabular}{|c|c|c|c|c|c|c|c|c|c|}
\hline $\begin{array}{l}\text { Date } \\
\text { interval } 1 \\
\text { May-31 } \\
\text { April }\end{array}$ & $\begin{array}{l}\text { Change in } \\
\text { coral cover }\end{array}$ & $\begin{array}{l}\text { Standard } \\
\text { deviation of } \\
\text { change in } \\
\text { coral cover }\end{array}$ & $\begin{array}{c}\text { Mean } \\
\text { annual SST }\end{array}$ & $\begin{array}{l}\text { Standard } \\
\text { deviation of } \\
\text { the annual } \\
\text { mean SST }\end{array}$ & $\begin{array}{c}\text { Annual SST } \\
\text { variance }\end{array}$ & $\begin{array}{l}\text { Minimum } \\
\text { SST weekly } \\
\text { mean }\end{array}$ & $\begin{array}{l}\text { Maximum } \\
\text { SST weekly } \\
\text { mean }\end{array}$ & $\begin{array}{c}\text { Number of } \\
\text { weekly } \\
\text { means } \\
\text { above } 30^{\circ} \mathrm{C}\end{array}$ & $\begin{array}{c}\text { Number of } \\
\text { weekly } \\
\text { means } \\
\text { above } \\
29.5^{\circ} \mathrm{C}\end{array}$ \\
\hline 1996-1997 & 0.018 & 0.193 & 26.480 & 2.042 & 4.171 & 23.027 & 30.378 & 1.000 & 1.000 \\
\hline 1997-1998 & -0.216 & 0.165 & 26.227 & 2.811 & 7.901 & 20.928 & 30.708 & 4.000 & 5.000 \\
\hline 1998-1999 & -0.233 & 0.201 & 26.504 & 2.442 & 5.962 & 22.704 & 30.341 & 3.000 & 8.000 \\
\hline $1999-2000$ & 0.014 & 0.137 & 26.240 & 2.457 & 6.037 & 21.842 & 30.461 & 3.000 & 5.000 \\
\hline $2000-2001$ & -0.001 & 0.181 & 25.938 & 2.523 & 6.367 & 20.745 & 29.891 & 0.000 & 1.000 \\
\hline 2001-2002 & 0.010 & 0.206 & 26.252 & 2.206 & 4.868 & 22.264 & 29.761 & 0.000 & 0.000 \\
\hline $2002-2003$ & -0.051 & 0.148 & 26.238 & 2.519 & 6.345 & 21.353 & 29.542 & 0.000 & 0.000 \\
\hline 2003-2004 & -0.065 & 0.229 & 26.270 & 2.466 & 6.079 & 22.036 & 29.550 & 0.000 & 0.000 \\
\hline 2004-2005 & 0.001 & 0.185 & 26.056 & 2.613 & 6.827 & 22.294 & 30.376 & 1.000 & 1.000 \\
\hline 2005-2006 & -0.192 & 0.174 & 25.916 & 2.747 & 7.543 & 21.151 & 30.373 & 3.000 & 5.000 \\
\hline 2006-2007 & 0.091 & 0.215 & 26.418 & 2.342 & 5.487 & 21.806 & 29.738 & 0.000 & 0.000 \\
\hline 2007-2008 & 0.085 & 0.216 & 26.531 & 2.345 & 5.498 & 23.260 & 30.164 & 2.000 & 7.000 \\
\hline
\end{tabular}

[59] reported declines in live coral cover of up to $44 \%$ between 1982 and 1991 at five out of six locations along the Florida reef tract. About $70 \%$ of the decline documented by CREMP since 1996 occurred in 1997-1999. In 1996, white pox disease, which apparently affects Acropora palmata exclusively, was first documented in the FKNMS [62]. Nearly 90\% of the A. palmata loss between 1996 and 2002 was attributed to white-pox disease [63]. CREMP has found an average decline in coral cover from $\sim 12 \%$ in 2000 to $~ 7 \%$ in 2008 [47]. Though multiple stressors and the proliferation of diseases have certainly played a role in the decline of coral populations in the Florida reef tract (e.g., $[36,64,65]$ ), a major factor contributing to coral mortality has been extremes in temperature, both warm, and cold events.

The original goal for this study was to study aspects of the intermediate disturbance model of Connell [24], and specifically to see whether SST variance can serve as an index of disturbance for coral reefs. Given that frequent disturbance events have resulted in precipitous decline in coral cover over the past $40-50$ years, we predicted that coral populations should be most resilient (that is, more likely to survive some disturbances and recover more quickly from others), at sites with intermediate intra-annual SST variance. We further predicted that sites with generally low SST variance likely experienced major loss in coral cover, reflecting historically higher prevalence of vulnerable species and of narrower acclimatization of all species.

Our study of weekly SST variance over 15 years (19942008) in waters of the Florida reef tract revealed that stony-coral cover was generally more stable (i.e., showed smaller declines) on reefs that experienced intermediate SST variability (mean variance $\sim 6-10^{\circ} \mathrm{C}$ ). The exception was Smith Shoal, which is routinely exposed to environmental extremes known to exceed the threshold of coral survival. Our results are similar to conclusions reached in three previous studies for coral communities in other places around the world $[17,19,21]$. This supports the concept that some coral species acclimate and adapt to substantial changes in temperature, yet extreme environmental conditions will lead to the death of large numbers of organisms even in these communities.

Over the 15-year period studied, both change in coral cover and percent coral cover in 2008 were correlated with SST variance consistent with the intermediate disturbance model. The time series revealed that years with the highest variance $\left(>7^{\circ} \mathrm{C}\right)$ showed the greatest disturbance $(>20 \%$ coral cover lost), while years with intermediate SST variances $\left(6-7^{\circ} \mathrm{C}\right)$ showed limited or no loss of coral cover. Years with very low SST variances (less than $5^{\circ} \mathrm{C}$ ) also had little or no loss in coral cover, with one exception (1998-1999). In that case, in the late summer of 1998, Florida reefs experienced 8 weeks with SSTs above $29.5^{\circ} \mathrm{C}$ and 4 weeks over the $30^{\circ} \mathrm{C}$. In addition to temperature extremes, coral mortality was also found after Hurricane Georges crossed the reef tract in September $1998[32,36]$.

The CREMP data set provided additional examples of how factors other than temperature contributed to observed rates of decline in coral cover on some reefs. For example, Smith Shoal showed the highest overall mean variance in temperature and featured relatively low coral cover (mean variance of SST $=\sim 11^{\circ} \mathrm{C}$ and $\sim 3 \%$ coral cover in 2008). This site is located to the north of the Florida reef tract, bordering Florida Bay. Smith Shoal regularly experiences extreme fluctuations in sediment load, salinity, and anomalous conditions such as "black water" events [66]. The 2002 "black water" event alone was associated with a reduction of nearly $68 \%$ of coral cover at Smith Shoal [66]. The large ( $>60 \mathrm{~km}$ diameter) dark patch of water contained a diatom bloom and red-tide organisms; associated stagnation of the water for up to two months near Smith Shoal apparently triggered the mortality of many benthic organisms.

Another aspect of the intermediate disturbance hypothesis is that species richness should vary with the frequency and intensity of disturbance events. At a low frequency 
of disturbance events, taxa that are highly competitive for space can dominate, resulting in somewhat reduced local species richness or at least increased dominance by a few species. Intermediate disturbance opens space for less competitive, more opportunistic taxa to recruit, often resulting in maximum local species richness. Environmental extremes restrict suitable substratum to the most tolerant or to opportunistic species, typically resulting in reduced species richness $[24,26]$.

Prior to the 1980s, Acropora spp. were major reef builders along the Florida reef tract, often dominating shallow offshore reefs $[32,36,67]$. These acroporids can be excellent competitors for space; with limited disturbance they can form nearly monospecific thickets [68, 69]. Early studies found that disturbance events such as thermal extremes or hurricanes resulted in high mortality of acroporids with subsequent recovery (e.g., [70, 71]). The 95\% loss of Acropora spp. reported in the Dry Tortugas during the cold-water event in the late 1970s [12, 51] was not anticipated to have been catastrophic. However, the subsequent proliferation of diseases and repeated bleaching events have since resulted in the long-term decline of Acropora spp. and minimal opportunities for recovery [32, 36, 47, 63, 72].

The CREMP data indicated that mean species richness declined by 2.3 species per station since 1996 and 1.8 species per station since 1999 in the 3 sites at Dry Tortugas [47]. The latest CREMP project report [47] finds that of the five dominant species (Montastraea cavernosa, M. annularis, Siderastrea siderea, Porites astreoides, and Colpophyllia natans), only S. siderea cover has not declined. This suggests that this species may be more resilient or resistant to SST events and other disturbances in the FKNMS. As noted above, Acropora spp. had already declined precipitously before the CREMP assessments began. Thus, the species that were among the best competitors for space under low disturbance conditions were no longer among the dominant species on the Florida reef tract, even while still present in low numbers.

Sea surface temperatures, temperature anomalies, and degree-heating weeks have proven to be important predictors of the potential for mass bleaching events on a regional scale [73-76]. However, they are not as useful in predicting local differences in the extent of bleaching, related mortality, and adaptation and/or acclimatization potential [77]. This study addressed the paradox that patch reefs along the Florida reef tract have exhibited less decline in coral cover than the offshore reefs, despite greater variability in temperature at the patch reefs. Similarly, offshore reefs that experienced intermediate temperature variability tended to experience less decline in coral cover over the 15-year study period. Our conclusion from these observations is that coral populations on reefs exhibiting moderate, but not extreme, SST variability are better able to survive extreme temperature events than populations on reefs exhibiting more limited temperature extremes.

The reefs of the Florida Keys are exposed to greater annual variability in temperature than coral reefs at lower latitudes in the Caribbean Sea. However, even in areas that do not experience such extreme winter temperatures, there can be local differences in SST variance experienced by coral populations with the potential for greater resilience in populations that experience moderate variability, as compared with populations that are generally exposed to minimal temperature stress.

Satellite-derived SST observations provide a tool to quickly assess patterns of variability over large spatial scales and over long periods of time. However, they do not provide the three-dimensional temperature history experienced by each coral organism [78]. Further research is needed to understand how temperature adaptation and tolerance to extreme temperatures evolve, and how they influence the distribution and survival of reef-building corals in the Florida Keys and Caribbean wide. Other factors like variations in bottom temperature, upwelling events, nutrient and sediment loads, UV radiation, harmful algal blooms, bacterial diseases, sewage outflow, ocean acidification, and other stressors all affect the resilience of reef-building corals. Indeed, it is essential to understand the natural stresses that these reefs are exposed to in order to properly manage anthropogenic factors, such as coastal development, divers, fishers, and others, that have an aggravating impact on reefs facing higher variability in a scenario of a changing climate.

\section{Acknowledgments}

The satellite data collection and processing conducted in support of this study was enabled by NASA grants NGT5-30414 and NNS04AB59G. I. M. Soto was supported by the Florida Georgia Louis Stokes for Alliance Minority Participation (FGLSAMP) Bridge to the Doctorate fellowship from the National Science Foundation, as part of a grant award to Dr. Ashanti Pyrtle and Dr. Shekhar Bhansali (University of South Florida). The authors thank the CREMP working group, especially Michael Callahan, Dr. David Palandro, and Rob Ruzicka of the Florida Marine Research Institute for facilitating access to the Coral Reef and Evaluation Monitoring Program (CREMP) data and for their insightful comments. They are also thankful to the anonymous reviewers and the Editor, whose comments helped improved this paper. IMaRS contribution 141.

\section{References}

[1] P. W. Glynn, "Coral reef bleaching: facts, hypotheses and implications," Global Change Biology, vol. 2, no. 6, pp. 495509, 1996.

[2] O. Hoegh-Guldberg, "Climate change, coral bleaching and the future of the world's coral reefs," Marine and Freshwater Research, vol. 50, no. 8, pp. 839-866, 1999.

[3] T. Goreau, T. McClanahan, R. Hayes, and A. Strong, "Conservation of coral reefs after the 1998 global bleaching event," Conservation Biology, vol. 14, no. 1, pp. 5-15, 2000.

[4] R. Berkelmans, "Time-integrated thermal bleaching thresholds of reefs and their variation on the Great Barrier Reef," Marine Ecology Progress Series, vol. 229, pp. 73-82, 2002.

[5] J. M. West and R. V. Salm, "Resistance and resilience to coral bleaching: implications for coral reef conservation and management," Conservation Biology, vol. 17, no. 4, pp. 956967, 2003. 
[6] A. C. Baker, C. J. Starger, T. R. McClanahan, and P. W. Glynn, "Corals' adaptive response to climate change: shifting to new algal symbionts may safeguard devastated reefs from extinction," Nature, vol. 430, no. 7001, p. 741, 2004.

[7] P. W. Glynn and L. D'Croz, "Experimental evidence for high temperature stress as the cause of El Niño-coincident coral mortality," Coral Reefs, vol. 8, no. 4, pp. 181-191, 1990.

[8] P. W. Glynn and W. H. de Weerdt, "Elimination of two reefbuilding hydrocorals following the 1982-83 El Niño warming event," Science, vol. 253, no. 5015, pp. 69-71, 1991.

[9] B. E. Brown, "Coral bleaching: causes and consequences," Coral Reefs, vol. 16, no. 1, pp. S129-S138, 1997.

[10] T. P. Hughes, A. H. Baird, D. R. Bellwood et al., "Climate change, human impacts, and the resilience of coral reefs," Science, vol. 301, no. 5635, pp. 929-933, 2003.

[11] A. C. Baker, P. W. Glynn, and B. Riegl, "Climate change and coral reef bleaching: an ecological assessment of longterm impacts, recovery trends and future outlook," Estuarine, Coastal and Shelf Science, vol. 80, no. 4, pp. 435-471, 2008.

[12] H. H. Roberts, J. L. Rouse, N. D. Walker, and J. H. Hudson, "Cold-water stress in Florida Bay and northern Bahamas: a product of winter cold-air outbreaks," Journal of Sedimentary Petrology, vol. 52, no. 1, pp. 145-155, 1982.

[13] O. Hoegh-Guldberg, M. Fine, W. Skirving, R. Johnstone, S. Dove, and A. Strong, "Coral bleaching following wintry weather," Limnology and Oceanography, vol. 50, no. 1, pp. 265271, 2005 .

[14] S. A. Wooldridge, "Water quality and coral bleaching thresholds: formalising the linkage for the inshore reefs of the Great Barrier Reef, Australia," Marine Pollution Bulletin, vol. 58, no. 5, pp. 745-751, 2009.

[15] S. A. Wooldridge and T. J. Done, "Improved water quality can ameliorate effects of climate change on corals," Ecological Applications, vol. 19, no. 6, pp. 1492-1499, 2009.

[16] R. Berkelmans and B. L. Willis, "Seasonal and local spatial patterns in the upper thermal limits of corals on the inshore Central Great Barrier Reef," Coral Reefs, vol. 18, no. 3, pp. 219228, 1999.

[17] T. R. McClanahan, M. Ateweberhan, C. A. Muhando, J. Maina, and M. S. Mohammed, "Effects of climate and seawater temperature variation on coral bleaching and mortality," Ecological Monographs, vol. 77, no. 4, pp. 503-525, 2007.

[18] P. W. Sammarco, A. Winter, and J. C. Stewart, "Coefficient of variation of sea surface temperature (SST) as an indicator of coral bleaching," Marine Biology, vol. 149, no. 6, pp. 1337$1344,2006$.

[19] T. R. McClanahan and J. Maina, "Response of Coral Assemblages to the Interaction between Natural Temperature Variation and Rare Warm-Water Events," Ecosystems, vol. 6, no. 6, pp. 551-563, 2003.

[20] T. R. McClanahan, M. Ateweberhan, N. A. J. Graham et al., "Western Indian Ocean coral communities: bleaching responses and susceptibility to extinction," Marine Ecology Progress Series, vol. 337, pp. 1-13, 2007.

[21] M. Ateweberhan and T. R. McClanahan, "Relationship between historical sea-surface temperature variability and climate change-induced coral mortality in the western Indian Ocean," Marine Pollution Bulletin, vol. 60, no. 7, pp. 964-970, 2010.

[22] D. M. Thompson and R. van Woesik, "Corals escape bleaching in regions that recently and historically experienced frequent thermal stress," Proceedings of the Royal Society B, vol. 276, no. 1669, pp. 2893-2901, 2009.
[23] J. Maina, V. Venus, T. R. McClanahan, and M. Ateweberhan, "Modelling susceptibility of coral reefs to environmental stress using remote sensing data and GIS models," Ecological Modelling, vol. 212, no. 3-4, pp. 180-199, 2008.

[24] J. H. Connell, "Diversity in tropical rain forests and coral reefs. High diversity of trees and corals is maintained only in a nonequilibrium state," Science, vol. 199, no. 4335, pp. 13021310, 1978.

[25] J. W. Porter, J. D. Woodley, G. J. Smith, J. E. Neigel, J. F. Battey, and D. G. Dallmeyer, "Population trends among Jamaican reef corals," Nature, vol. 294, no. 5838, pp. 249-250, 1981.

[26] S. L. Collins, S. M. Glenn, and D. J. Gibson, "Experimental analysis of intermediate disturbance and initial floristic composition: decoupling cause and effect," Ecology, vol. 76, no. 2, pp. 486-492, 1995.

[27] J. H. Connell, T. P. Hughes, C. C. Wallace, J. E. Tanner, K. E. Harms, and A. M. Kerr, "A long-term study of competition and diversity of corals," Ecological Monographs, vol. 74, no. 2, pp. 179-210, 2004.

[28] J. M. Johns, V. M. Leeworthy, F. W. Bell, and M. A. Bonn, "Socio-economic study of reefs in Southeast Florida final report," Tech. Rep., Hazen and Sawyer, NOAA, Florida Fish and Wildlife Commission, 2001.

[29] W. C. Jaap, "Observation on zooxanthellae expulsion at Middle Sambo Reef, Florida Keys," Bulletin of Marine Science, vol. 29, pp. 414-422, 1979.

[30] P. Dustan and J. C. Halas, "Changes in the reef-coral community of Carysfort reef, Key Largo, Florida: 1974 to 1982," Coral Reefs, vol. 6, no. 2, pp. 91-106, 1987.

[31] B. Causey, J. Delaney, E. Diaz et al., "Status of coral reefs in the U.S. Caribbean and Gulf of Mexico: Florida, Texas, Puerto Rico, US Virgin Islands, Navassa," in Status of Coral of the World, C. R. Wilkinson, Ed., GCRMN Report, p. 276, Australian Institute of Marine Science, Townsville, Queensland, Australia, 2002.

[32] J. W. Porter, V. Kosmynin, K. L. Patterson et al., "Detection of coral reef change by the Florida Keys Coral Reef Monitoring Project," in The Everglades, Florida Bay, and Coral Reefs of the Florida Keys: An Ecosystem Handbook, J. W. Porter and K. G. Porter, Eds., pp. 749-769, CRC Press, Boca Raton, Fla, USA, 2002.

[33] B. D. Keller and B. D. Causey, "Linkages between the Florida Keys National Marine Sanctuary and the South Florida Ecosystem Restoration Initiative," Ocean and Coastal Management, vol. 48, no. 11-12, pp. 869-900, 2005.

[34] J. C. Ogden, J. W. Porter, N. P. Smith, A. M. Szmant, W. J. Jaap, and D. Forcucci, "A long-term interdisciplinary study of the Florida Keys seascape," Bulletin of Marine Science, vol. 54, no. 3, pp. 1059-1071, 1994.

[35] J. L. Wheaton, W. C. Jaap, P. Dustan, J. Porter, and O. Meier, "Florida Keys National Marine Sanctuary water quality protection plan, coral reef and hardbottom monitoring project," Tech. Rep., Florida Fish and Wildlife Conservation Commission, 1996.

[36] W. C. Jaap, A. Szmant, K. Jaap et al., "A perspective on the biology of Florida coral reefs," in Coral Reefs of the USA, B. M. Riegl and R. E. Dodge, Eds., pp. 75-125, Springer, Amsterdam, The Netherlands, 2008.

[37] W. C. Jaap, J. L. Wheaton, K. E. Hackett et al., "Long-term (1989-2002) monitoring of selected coral reef sites at Dry Tortugas National Park," Tech. Rep., Florida Fish and Wildlife Conservation Commission, 2002. 
[38] P. J. Somerfield, W. C. Jaap, K. R. Clarke et al., "Changes in coral reef communities among the Florida Keys, 1996-2003," Coral Reefs, vol. 27, no. 4, pp. 951-965, 2008.

[39] N. P. Smith, "Long-term Gulf-to-Atlantic transport through tidal channels in the Florida Keys," Bulletin of Marine Science, vol. 54, no. 3, pp. 602-609, 1994.

[40] R. N. Ginsburg, E. Gischler, and W. E. Kiene, "Partial mortality of massive reef-building corals: an index of patch reef condition, Florida Reef Tract," Bulletin of Marine Science, vol. 69, no. 3, pp. 1149-1173, 2001.

[41] D. E. Wagner, P. Kramer, and R. van Woesik, "Species composition, habitat, and water quality influence coral bleaching in southern Florida," Marine Ecology Progress Series, vol. 408, pp. 65-78, 2010.

[42] S. L. Coles and B. E. Brown, "Coral bleaching - capacity for acclimatization and adaptation," Advances in Marine Biology, vol. 46, pp. 183-223, 2003.

[43] E. P. McClain, W. G. Pichel, C. C. Walton, Z. Ahmad, and J. Sutton, "Multi-channel improvements to satellite-derived global sea surface temperatures," Advances in Space Research, vol. 2, no. 6, pp. 43-47, 1982.

[44] C. Hu, F. Muller-Karger, B. Murch et al., "Building an automated integrated observing system to detect sea surface temperature anomaly events in the Florida Keys," IEEE Transactions on Geoscience and Remote Sensing, vol. 47, no. 6, Article ID 4783020, pp. 1607-1620, 2009.

[45] D. Wagner, E. Mielbrecht, and R. van Woesik, "Application of landscape ecology to spatial variance of water-quality parameters along the Florida Keys reef tract," Bulletin of Marine Science, vol. 83, no. 3, pp. 553-569, 2008.

[46] C. R. Beaver, W. C. Jaap, J. W. Porter et al., "Coral Reef Evaluation and Monitoring Project (CREMP)," Tech. Rep., Executive Summary, Florida Fish and Wildlife Conservation Commission, 2004.

[47] R. Ruzicka, K. Semon, M. Colella et al., "CREMP 2009 final report," Tech. Rep., Fish and Wildlife Research Institute/Florida Fish and Wildlife Conservation Commission, Saint Petersburg, Fla, USA, 2010.

[48] E. A. Shinn, "Coral growth rate, an environmental indicator," Journal of Paleontology, vol. 40, no. 2, pp. 233-240, 1966.

[49] J. H. Hudson, E. A. Shinn, R. B. Halley, and B. Lidz, "Autopsy of a dead coral reef," American Association Petroleum Geologists Bulletin, vol. 60, no. 4, p. 682, 1976.

[50] G. E. Davis, "A century of natural change in coral distribution at the Dry Tortugas: a comparison of reef maps from 1881 and 1976," Bulletin of Marine Science, vol. 32, no. 2, pp. 608-623, 1982.

[51] J. W. Porter, J. Battey, and G. Smith, "Perturbation and change in coral reef communities," Proceedings of the National Academy of Science, vol. 79, pp. 1678-1681, 1982.

[52] The Nature Conservancy Press Release, "Extend of cold impact on Florida Keys corals," 2010, http://www.nature.org/wherewework/northamerica/states/florida/press/press4413.html.

[53] W. B. Gladfelter, "White band disease in Acropora palmata: implications for the structure and growth of shallow reefs," Bulletin of Marine Science, vol. 32, pp. 639-643, 1982.

[54] W. C. Jaap, J. C. Halas, and R. G. Muller, "Community dynamics of stony corals (Milleporina and Scleractinia) at Key Largo National Marine Sanctuary, Florida, during 19811986," in Proceedings of the 6th International Coral Reef Symposium, vol. 2, pp. 237-243, 1988.
[55] E. C. Peters, "A survey of cellular reactions to environmental stress and disease in Caribbean scleractinian corals," Helgoländer Meeresuntersuchungen, vol. 37, no. 1-4, pp. 113-137, 1984.

[56] W. C. Jaap, "An epidemic zooxanthellae expulsion during 1983 in the lower Florida Keys coral reefs: hyperthermic etiology," in Proceedings of the 5th International Coral Reef Congress, vol. 6, pp. 142-148, 1985.

[57] J. C. Lang, H. R. Lasker, E. H. Gladfelter et al., "Spatial and temporal variability during periods of "recovery" after mass bleaching on Western Atlantic coral reefs," Integrative and Comparative Biology, vol. 32, no. 6, pp. 696-706, 1992.

[58] H. A. Lessios, "Mass mortality of Diadema antillarum in the Caribbean: what have we learned?" Annual Review of Ecology and Systematics, vol. 19, pp. 371-393, 1988.

[59] J. W. Porter and O. W. Meier, "Quantification of loss and change in Floridian reef coral populations," American Zoologist, vol. 32, no. 6, pp. 625-640, 1992.

[60] E. C. Peters, "Diseases of coral reef organisms," in Life and Death of Coral Reefs, C. Birkeland, Ed., pp. 114-139, Chapman \& Hall, New York, NY, USA, 1997.

[61] D. L. Santavy, E. Mueller, E. C. Peters et al., "Quantitative assessment of coral diseases in the Florida Keys: strategy and methodology," Hydrobiologia, vol. 460, pp. 39-52, 2001.

[62] C. Holden, "Coral disease hot spot in Florida keys," Science, vol. 274, no. 5295, p. 2017, 1996.

[63] K. P. Sutherland and K. B. Ritchie, "White pox disease of the Caribbean elkhorn coral, Acropora palmata," in Coral Health and Disease, E. Rosenberg and Y. Loya, Eds., pp. 280-300, Springer, Berlin, Germany, 2004.

[64] P. Dustan, "Coral reefs under stress: sources of mortality in the Florida keys," Natural Resources Forum, vol. 23, no. 2, pp. 147-155, 1999.

[65] J. W. Porter, S. K. Lewis, and K. G. Porter, "The effect of multiple stressors on the Florida Keys coral reef ecosystem: a landscape hypothesis and a physiological test," Limnology and Oceanography, vol. 44, no. 3, pp. 941-949, 1999.

[66] C. Hu, K. E. Hackett, M. K. Callahan et al., "The 2002 ocean color anomaly in the Florida Bight: a cause of local coral reef decline?" Geophysical Research Letters, vol. 30, no. 3, pp. 11511154, 2003.

[67] E. A. Shinn, J. H. Hudson, R. B. Halley, and B. Lidz, "Topographic control and accumulation rates of some Holocene coral reefs: south Florida and Dry Tortugas," in Proceedings of the 3rd International Coral Reef Symposium, vol. 2, pp. 17, 1977.

[68] V. Tunnicliffe, "Caribbean staghorn coral populations: preHurricane Allen conditions in Discovery Bay, Jamaica," Bulletin of Marine Science, vol. 33, no. 1, pp. 132-151, 1983.

[69] B. Vargas-Ángel, J. D. Thomas, and S. M. Hoke, "High-latitude Acropora cervicornis thickets off Fort Lauderdale, Florida, USA," Coral Reefs, vol. 22, no. 4, pp. 465-473, 2003.

[70] M. M. Ball, E. A. Shinn, and K. W. Stockman, "The geological effects of hurricane Donna in South Florida," Journal of Geology, vol. 75, no. 5, pp. 583-697, 1967.

[71] W. C. Jaap, "Boom-bust cycles in Acropora," Reef Encounter, vol. 23, pp. 12-13, 1998.

[72] W. C. Jaap and J. W. Wheaton, "Annual report for amendment 5, sub-agreement CA-500009027/1, cooperative agreement CA-5000-8-8014. U.S. National Park Service, US Dept Interior: benthic coral reef monitoring at Dry Tortugas National Park," Tech. Rep., 1995. 
[73] A. E. Strong, C. S. Barrientos, C. Duda, and J. Sapper, "Improved satellite techniques for monitoring coral bleaching," in Proceedings of the 8th International Coral Reef Symposium, vol. 2, pp. 1495-1498, 1997.

[74] J. J. McCarthy, O. F. Canziani, N. A. Leary, D. J. Dokken, and K. S. White, Climate Change 2001: Impacts, Adaptation, and Vulnerability, Contribution of Working Group 2nd to the 3rd Assessment Report of the Intergovernmental Panel on Climate Change (IPCC), Cambridge University Press, Cambridge, UK, 2001.

[75] G. Liu, A. E. Strong, W. Skirving, and L. F. Arzayus, "Overview of NOAA coral reef watch program's near-real time satellite global coral bleaching monitoring activities," in Proceedings of the 10th International Coral Reef Symposium, vol. 1, pp. 17831793, 2005.

[76] D. P. Manzello, R. Berkelmans, and J. C. Hendee, "Coral bleaching indices and thresholds for the Florida Reef Tract, Bahamas, and St. Croix, US Virgin Islands," Marine Pollution Bulletin, vol. 54, no. 12, pp. 1923-1931, 2007.

[77] T. R. McClanahan, M. Ateweberhan, C. Ruiz Sebastián et al., "Predictability of coral bleaching from synoptic satellite and in situ temperature observations," Coral Reefs, vol. 26, no. 3, pp. 695-701, 2007.

[78] J. J. Leichter, B. Helmuth, and A. M. Fischer, "Variation beneath the surface: quantifying complex thermal environments on coral reefs in the Caribbean, Bahamas and Florida," Journal of Marine Research, vol. 64, no. 4, pp. 563-588, 2006. 

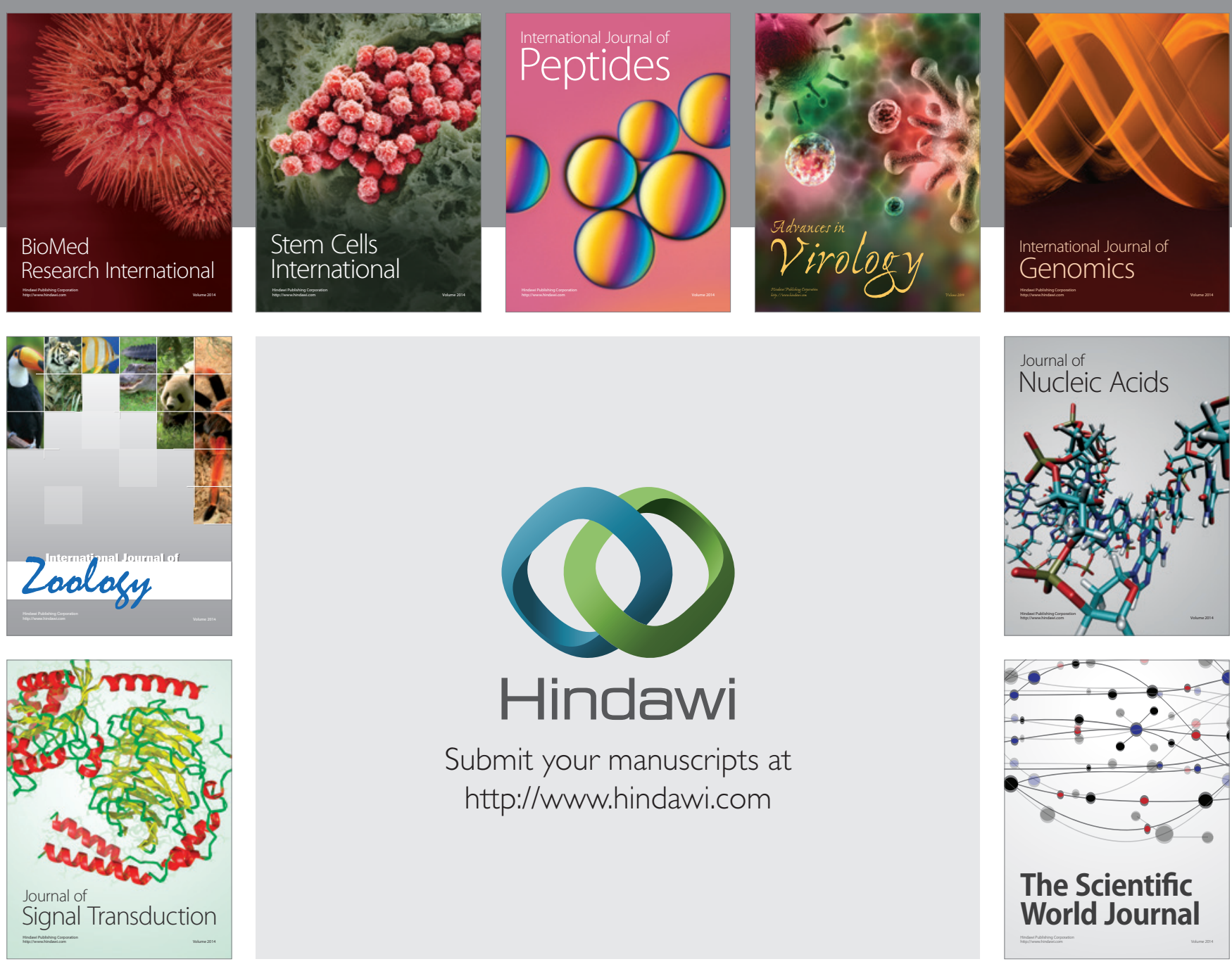

Submit your manuscripts at

http://www.hindawi.com
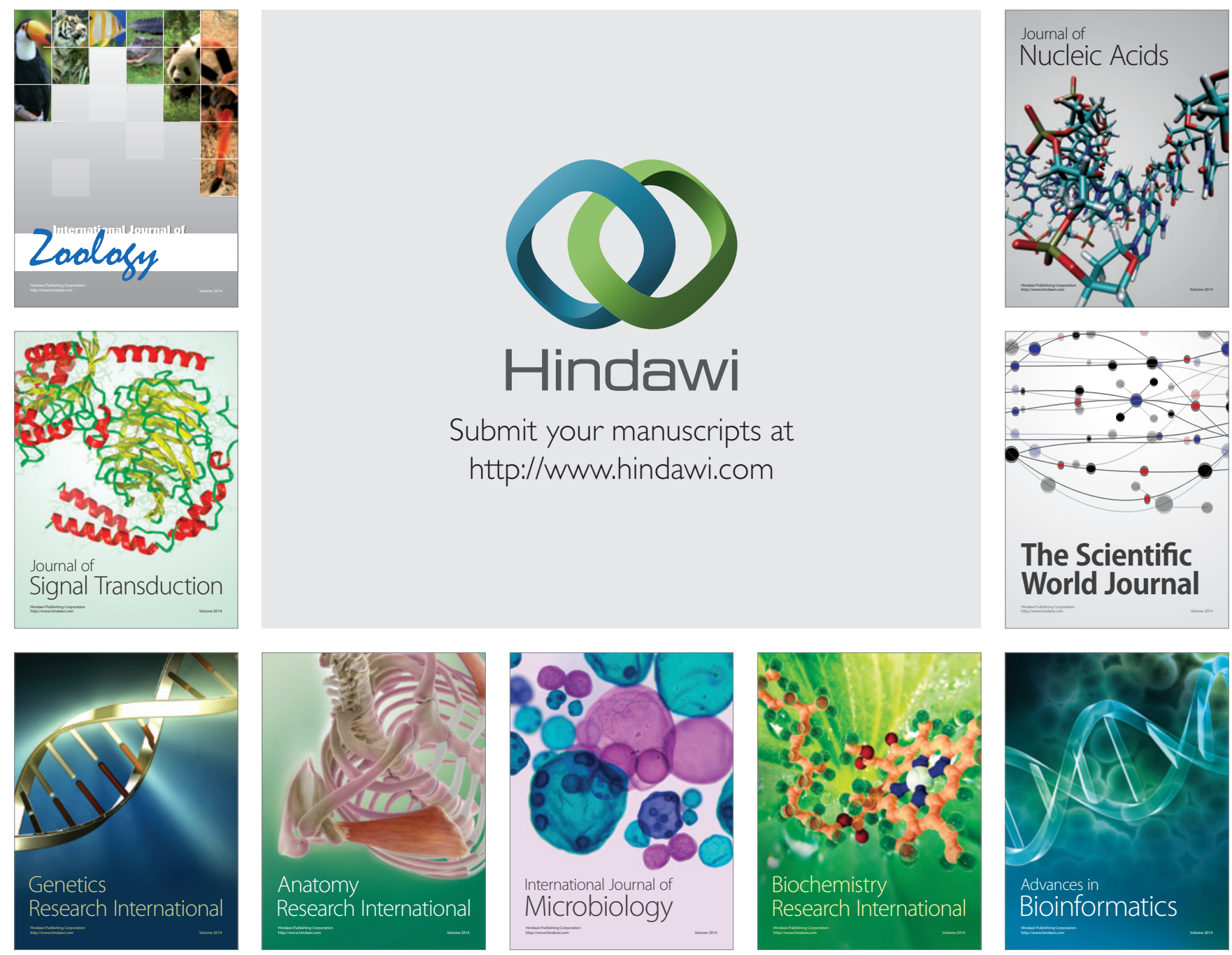

The Scientific World Journal
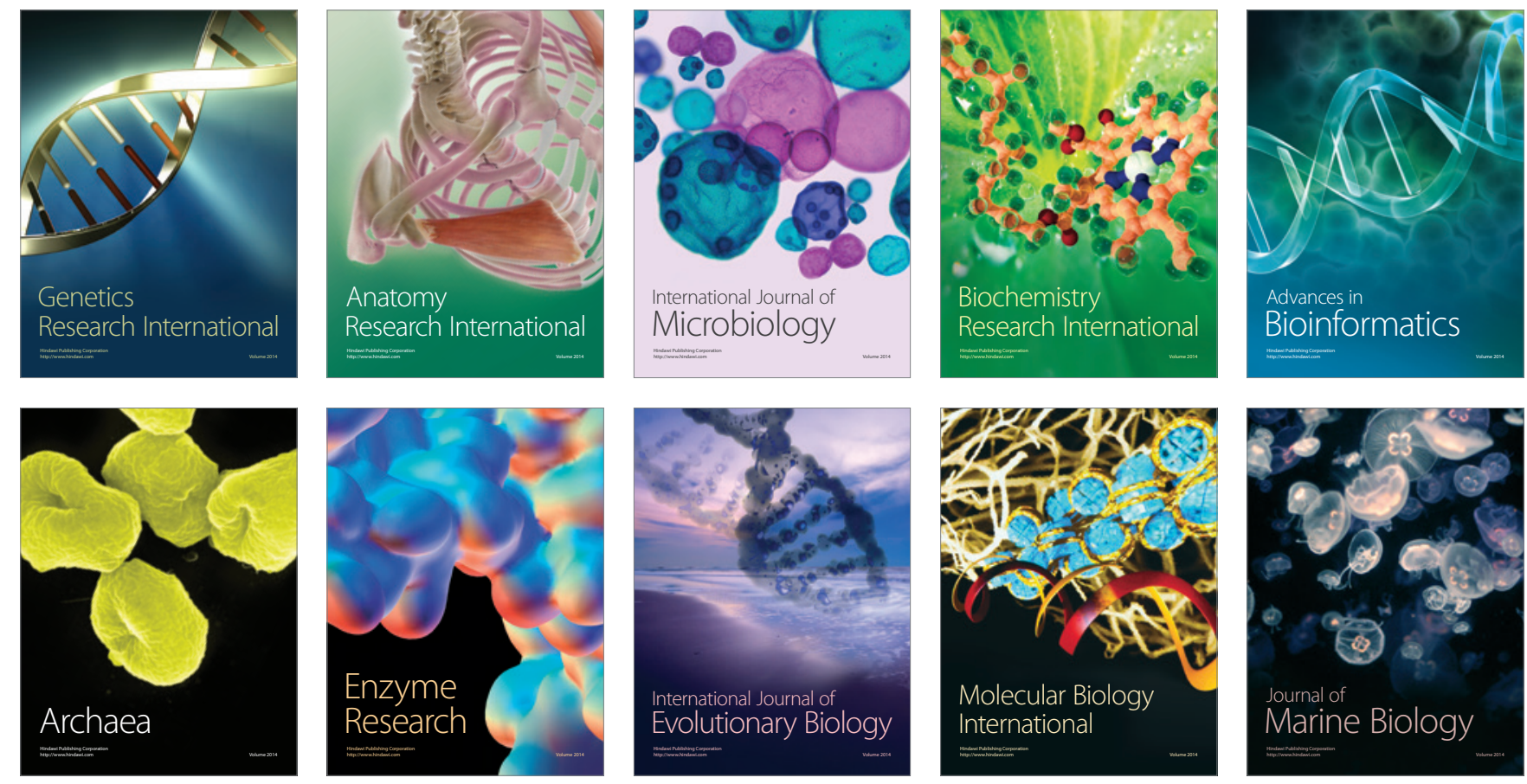